Artigos 


\section{As biotecnologias no início dos anos noventa: êxitos, perspectivas e desafios}

\section{FEDERICO MAYOR}

$\mathrm{N}$

To informe publicado em 1982 pela Organização de Cooperação e Desenvolvimento Econômico (Bull \& Lilly, 1982), definia-se técnicos ao tratamento de matérias por agentes biológicos para obter bens e serviços". Os agentes biológicos a que se refere esta definição são principalmente microorganismos, células animais e vegetais e enzimas. Os bens e serviços são os produtos das indústrias do ramo de alimentação, bebidas, farmácia e biomedicina.

Portanto, as biotecnologias compreendem todos os processos de transformação de matérias-primas renováveis, e os de produção, mediante cultivos celulares microbianos, animais e vegetais, ou seus distintos componentes, de numerosas substâncias úteis para a humanidade.

Os progressos da biologia molecular, da genética e do metabolismo bacteriano contribuíram para o desenvolvimento das biotecnologias, sobretudo graças ao emprego da mutação e da seleção de cepas mais eficazes e com maior rendimento. Posteriormente, o desenvolvimento dos processos de fermentaçáo contínua e o descobrimento de métodos de imobilização de enzimas tiveram a maior importância. Desde meados do decênio de 1970, o grande avanço que possibilitou o descobrimento de endonucleoses, ou enzimas de restrição, ligantes e técnicas de clonagem de genes, assim como produçáo de anticorpos monoclonais pela técnica de hibridomas, abriu caminho para a chamada revolução biotecnológica. $\mathrm{O}$ último avanço técnico foi a possibilidade de aumentar consideravelmente a quantidade de $\mathrm{ADN}$, isto é, do suporte molecular do patrimônio hereditário de todo ser vivo, graças à reação em cadeia da polimerização ou PCR (Polymerase Chain Reaction). Assim, a partir de uma célula ou de um fragmento minúsculo de tecido, pode-se ampliar a quantidade infinitesimal de ADN presente e contar 
com quantidades muito mais representativas, facilitando as experiências de clonagem.

Essas novas técnicas - conhecidas como engenharia genética ou técnicas de recombinaçáo do $\mathrm{ADN}$ - contribuem para que se conheçam melhor as regras dos genes e sua expressáo celular, tendo também aplicaçóes em farmácia, medicina, veterinária, agricultura, alimentaçáo e nutrição, bioenergia etc. Além da reproduçáo convencional por hibridaçáo e cruzamento na mesma espécie ou entre espécies distintas, as técnicas de recombinação do $\mathrm{ADN}$ podem produzir micróbios, vegetais e animais transgenéticos com novos genes que controlam a produçăo de substâncias úteis ou novas características desejáveis.

A definiçáo da OCDE, que goza de grande prestígio internacional, destaca como primeiro ponto básico as biotecnologias não serem disciplinas, mas campos de atividade. Sua base é multidisciplinar, e as disciplinas fundamentais são biologia molecular e celular, bioquímica, genética, microbiologia, imunologia, engenharia química e de processamento computacional, cálculo e processamento de dados. O segundo ponto básico refere-se à engenharia genética não ser biotecnologia, mas instrumento poderoso, na verdade uma série de técnicas, que têm e terão repercussões profundas nas biotecnologias; poderiam converter-se em instrumentos das biotecnologias futuras e tornarem-se excelentes para a agricultura e o tratamento das doenças genéticas do ser humano. Em 22 de maio de 1989 Rosenberg, French Anderson e Blaese, do National Cancer Institute de Bethesda (Maryland), realizaram o primeiro experimento de terapia genética em seres humanos, utilizando linfócitos manipulados geneticamente para estimular a produção de interleucina $2 \mathrm{em}$ paciente com câncer de pele, em fase terminal.

As biotecnologias podem aplicar-se a diversos setores econômicos e em diferentes graus de complexidade, investimento e esforço: por exemplo, em um departamento de pesquisa avançada em biologia molecular ou em unidades baratas de cultivo de tecidos vegetais, ou propagação clonal de uma espécie de cultivo comestível (Seasson, 1984 e 1988; Vasil, 1987 e 1990; Muñoz, 1992).

Os avanços das biotecnologias no início da década de 1990

Ao longo dos anos oitenta, paralelamente ao avanço das biotecnologias nos países industrializados, passou-se a ter visāo mais precisa e 
realista de suas conseqüências econômicas e sociais. Contrariamente ao que sucedia no Japáo e na Europa, nos Estados Unidos a concepçáo geral das biotecnologias limitou-se, nesse período, aos processos e produtos biológicos relacionados com a engenharia genética. A conseqüente concentração de esforços levou à descoberta e à fabricaçăo dos primeiros produtos comerciais derivados da biotecnologia, como insulina, hormônio de crescimento humano, ativador plasminógeno de tecidos e outros polipeptídeos e proteínas biologicamente ativos. Esses esforços para a consecuçáo de produtos farmacêuticos de pouco volume e grande valor sinérgico realizaram-se às expensas de trabalho mais convencional de pesquisa e desenvolvimento. A partir de entáo, a síndrome norteamericana NIMBY ( not in my backyard - no meu quintal, não) havia suscitado interesse renovado pelas biotecnologias convencionais, devido à intensa preocupação da sociedade com a conservação e manutenção do meio ambiente. Além disso, surgiu novo interesse pelos produtos comercializáveis de grande volume e reduzido valor sinérgico como, por exemplo, alimentos e combustíveis a partir de hidratos de carbono baratos.

No âmbito da medicina e da farmácia, além da produção mediante células microbianas ou animais com genoma modificado de substâncias medicamentosas (hormônios, trombolíticos, fatores da coagulação sangüínea, linfocinas, interferonas), a luta contra os vírus patogênicos baseia-se na determinação da estrutura molecular de seu genoma e de suas principais proteínas, objetivando preparar vacinas que bloqueiem sua ação. É o que acontece com o vírus da AIDS, cuja estrutura genética foi determinada apenas há alguns anos, com a descoberta da doença, em 1981, comprovando-se a supervariação da estrutura antigênica do vírus, isto é, sua capacidade para debilitar as defesas imunológicas do ser humano. Graças ao estudo molecular da estrutura do vírus, procura-se descobrir partes dessa estrutura que variem pouco e que possam ser inibidas. Outras vacinas, como a que foi feita contra a hepatite $B$, e que é amplamente comercializada hoje em dia, consistem em injetar um antígeno do vírus, sintetizado abundantemente por células de levedura ou células animais às quais se inoculou o gene correspondente; esse antígeno, isto é, uma proteína, estimula as defesas imunológicas do organismo humano, que será capaz de resistir quando estiver na presença do vírus. Cabe também atuar nos receptores de hormônios ou pequenas moléculas, como as que intervêm no funcionamento das células nervosas; nesse caso, partindo do esclarecimento da estrutura molecular desses receptores, procura-se sintetizar, com ajuda do computador, moléculas antagônicas que bloqueiem o funcionamento do receptor, impe- 
dindo a sua molécula complementar fixar-se nele, ou moléculas agonísticas, que têm o efeito contrário. Esse procedimento é a própria base da imunocontracepção, vacinas para prevenir a fecundidade feminina ou masculina.

O ritmo das descobertas propícias às biotecnologias no campo da agricultura e da alimentaf̧ão foi mais rápido que o previsto, durante os anos oitenta. No entanto, uma revolufãa dos conbecimentos não cede lugar imediatamente a outra revolução agricola; as modificaçóes provocadas na reprodução de plantas e animais e na produçáo de alimentos demorarão entre vinte a trinta anos para concretizar-se, em função de múltiplos fatores, muitos dos quais alheios ao âmbito da ciência e da tecnologia, isto é, problemas econômicos, jurídicos e de segurança, ações públicas e políticas industriais.

Com relação à reprodução e à melhoria dos cultivos, surgiram ensaios biotecnológicos rápidos para descobrir organismos patogênicos dos cultivos e controle da qualidade de sementes e safras, com o objetivo de conseguir que sua reprodução e comércio sejam mais seguros e eficientes, e facilitar a aplicação de normas juridicamente definidas. Os novos e eficientes métodos de modificação genética para aumentar o rendimento dos vegetais e sua resistência aos vírus e a outras doenças, assim como às tensóes abióticas, poderiam vir a ser a contribuição mais importante das biotecnologias vegetais. Desde 1982, ano em que se conseguiu transferir com êxito o primeiro gene isolado, os avanços têm sido muito rápidos, tendo-se modificado desde então várias dezenas de plantas. Em 1992 realizaram-se várias centenas de ensaios com plantas transgenéticas na Europa, Estados Unidos, Japão e Austrália.

A micropropagação in vitro e outras biotecnologias contribuíram para reduzir os longos e onerosos processos de produção, crescimento e avaliaçáo de numerosos vegetais. Além disso, estão sendo usados a cartografia genética, os inseticidas microbianos e os diagnósticos para doenças de plantas.

Finalmente, as biotecnologias vegetais trataram de melhorar a qualidade das plantas para que as partes colhidas se adaptem melhor ao seu uso final como nutrientes ou produtos não comestíveis.

As biotecnologias animais em exploração comercial envolvem: diagnósticos veterinários, vacinas e medicamentos novos, fecundação de embrióes in vitro, administração do hormônio de crescimento para favorecer este último e aumentar a produção leiteira, raçôes para animais e aditivos para as raçóes. Em 1992 não há no mercado animais domés- 
ticos transgenéticos, mas já houve várias tentativas com ovelhas $\mathrm{e}$ porcos. Os animais transgenéticos, por exemplo o onco-rato, têm sido utilizados em laboratórios como modelo das doenças humanas.

Entre as novas biotecnologias alimentares que têm atualmente aplicação comercial, cabe mencionar métodos biotecnológicos de verificação ou diagnóstico, bioconversão da fécula em produtos doces, aromatizantes e realçadores do sabor dos alimentos, tratamento dos sucos de frutas, aminoácidos e outros nutrientes especiais, pigmentos e vitaminas obtidos de microalgas, novos alimentos estruturados a partir da fermentação, enzimas do queijo, produtos lácteos sem lactose e híbridos da levedura.

No setor não alimenticio, têm sido comercializados vários produtos ou procedimentos baseados nas biotecnologias: bioconversáo da biomassa em metano ou etanol, por fermentação anaeróbica ou aeróbica, reprodução e propagaçáo seletivas de árvores e plantas ornamentais, cultivos de células vegetais e extração e tratamento enzimático aplicados a diversos produtos.

\section{Novidades previsíveis}

Diante da reação do consumidor, no setor alimentício não é provável a produção de novidades revolucionárias em futuro muito próximo. Alguns produtos serăo comercializados entre 1990-1995 como, por exemplo, fermento para pão geneticamente modificado, novos alimentos para necessidades nutricionais específicas, corantes e ingredientes alimentícios ou compostos com grande valor sinérgico obtidos de culturas de células de microalgas.

A médio prazo (1995-2000) poderiam ser comercializados outros produtos, como bactérias alimentares modificadas geneticamente para dar aroma e qualidade, enzimas alimentares modificadas, novos biocatalisadores para o tratamento dos alimentos e maior número de testes biológicos e bio-sensores rápidos para muitos produtos contaminadores dos alimentos.

As mudanças poderiam ser mais drásticas no setor dos cultivos. Os primeiros exemplares de batata, algodão, colza, tomate, tabaco e soja transgenéticos foram submetidos a experimentos em ensaios em pequena escala no terreno; entre essas espécies havia plantas transgenéticas resistentes a herbicidas, vírus e insetos específicos, e também outras com melhores características em termos de qualidade, que apresentavam inte- 
resse comercial. Espera-se a comercialização de algumas delas até 1995. Todavia, atrasos decorrentes dos requisitos de segurança, preocupaçóes do público e necessidade de efetuar mais pesquisa e desenvolvimento sobre os genes, farăo com que a comercialização em grande escala de culturas geneticamente modificadas ocorra $\mathrm{em}$ alguns países até o ano 2000 , e suas repercussóes só comecem realmente a se fazer sentir aproximadamente em 2005. Outro tanto se pode dizer do trigo, cuja transformaçăo foi conseguida em 1992 (Vasil et alii, 1992).

No setor animal, antes de 1995 estará sendo comercializado abundante instrumental novo de diagnóstico para detectar as doenças e avaliar a capacidade fecundadora do esperma, assim como novos medicamentos e vacinas (por exemplo, contra as doenças parasitárias). Serão comercializados também novos aditivos de raçăo, entre eles aminoácidos, antibióticos e microrganismos do rúmen e, talvez, o primeiro peixe transgenético. Espera-se para o período compreendido entre 1995 e 2000 o desenvolvimento dos gados suíno e bovino com rápido potencial de crescimento, melhor qualidade da carne e, no que se refere ao bovino, maior produção de leite, tudo graças à administração de hormônios de crescimento recombinados. Mesmo assim, a transferência de genes interessantes para outros animais poderia permitir a proliferaçáo de animais geneticamente superiores gerando, por exemplo, raças resistentes às doenças.

O máximo rendimento sustentável das pescarias convencionais oscila entre 100 e 120 milhóes de toneladas e, em 1990, estimava-se a pesca mundial em aproximadamente 100 milhóes de toneladas. Enquanto a porcentagem correspondente aos países em desenvolvimento das exportaçōes mundiais de pescado mantinha-se estável em $45 \%$, nos países industrializados correspondia aproximadamente a $90 \%$ das importaçóes totais de pescado em 1989. Nesses países, a preferência do consumo está passando da carne ao pescado. À aquiicultura já pode ser conferida parte do aumento das exportaçōes, que a aplicação das biotecnologias poderia favorecer.

Pescado, mariscos ou moluscos estéreis poderiam ser produzidos mediante poliploidia induzida. O pescado estéril cresce mais depressa, já que a contribuição de energia se canaliza nos músculos e não nos órgãos de reproduçáo. Por esse motivo, $40 \%$ das ostras criadas nos Estados Unidos são triplóides. Tetraplóides de truta irisada da segunda geração cruzaram-se com diplóides, para produzir $100 \%$ de triplóides, sumamente atrativos do ponto de vista comercial. 
$\mathrm{Na}$ década de 1970 e no início dos anos oitenta, os pesquisadores isolaram e purificaram hormônios de crescimento a partir da glândula pituitária de peixes e outros vertebrados. A produçáo de hormônios de crescimento do pescado por meio de células manipuladas geneticamente é considerada o meio mais eficaz. Em vários experimentos, os pescados em que se havia injetado o hormônio do crescimento tiveram seu peso dobrado em um período de sessenta dias, com relação à populaçáo de controle não tratada. Pela dificuldade na administraçăo do hormônio do crescimento aos pescados, a pesquisa concentrou-se na inserçáo do gene do hormônio no genoma do peixe. Até 1990, foi comunicada a existência de treze espécies de pescados transgenéticos. Além dos peixes de aquário, que servem como modelos na pesquisa fundamental, foram criadas variantes transgenéticas de espécies comerciais, como o salmáo do Atlântico, o salmonete do canal da Mancha, a carpa e a tilápia. Até 1992 náo havia sido patenteado qualquer pescado transgenético.

À medida que as granjas onde se pratica a aquiicultura aumentam sua produçáo por unidade, o controle efetivo das doenças e das tensóes adquirirá maior importância. Calculou-se que mais de $\mathbf{5 0 \%}$ da produçáo mundial total de pescado, marisco e molusco poderia perder-se devido a doenças. Assim como também se calcula que, até o ano 2000, 25\% do consumo mundial de produtos do mar estará coberto pela aqüicultura, e estima-se serem as vacinas importante setor de crescimento. Na Escandinávia e em alguns locais dos Estados Unidos, a quase totalidade das trutas e dos salmóes produzidos por aqüicultura estavam vacinados em 1989 , contra $5 \%$ em 1984.

Nos países industrializados, as macroalgas estáo sendo utilizadas principalmente como fonte de ficocolóides, de grande valor sinérgico e pouco volume, entre eles o ágar, o alginato e o carragaben. Este último, importante produto obtido das algas marinhas vermelhas, $\boldsymbol{\epsilon}$ muito utilizado como espessante em diversos alimentos e produtos afins, desde o leite condensado até os dentifrícios. $O$ ágar é usado como agente gelificante na eletroforese e na cromatografia. Os alginatos derivados de algas pardas incorporam-se a produtos lácteos e de panificaçăo, assim como ao dentifrício e ao xampu; utilizados também em tingimento e pintura, a maior parte da produção mundial de alginatos é empregada na indústria papeleira e têxtil. Em média, o consumidor ocidental absorve anualmente em sua dieta 100 gramas de ficocolóides.

A demanda de agarose, forma bastante purificada de ágar, aumenta constantemente, devido à generalização do emprego das técnicas da biologia molecular; conseqüentemente, aumenta a demanda de fontes 
de algas marinhas, Gelidium e Gracilaria. Também se aplicam as técnicas de fusão protoplástica para gerar novas cepas de algas marinhas que produzam ágar de boa qualidade. O cultivo marinho de Porphyra $e$ Macrocystis, na Colúmbia Britânica (Canadá), está passando das provas de viabilidade à produção comercial. Os pesquisadores da Universidade da Carolina do Norte empregaram técnicas de engenharia genética para hibridizar a Porphyra visando obter uma variedade geneticamente superior.

Não é esperado que o setor não alimentar, assim como o alimentar, experimente alguma mudança radical, a não ser maior aumento nos preços do petróleo cru, ou que se comece a taxar com impostos os combustíveis fósseis. Os cultivos transgenéticos para a produçăo de produtos já existentes ou de outros novos (produtos químicos refinados, produtos farmacêuticos, enzimas etc.) poderiam converter-se em realidade comercial, mas certamente não antes do ano 2000.

\section{Programa Genoma bumano}

O programa Genoma bumano, iniciado oficialmente em 1987 pelos Estados Unidos, é o mais ambicioso programa de pesquisa já abordado no campo da biologia. Objetiva decifrar a estrutura e a funçáo do conjunto do patrimônio hereditário da espécie humana, isto é, analisar as seqüências de $\mathrm{ADN}$ que constituem os genes e os cromossomos. $\mathrm{O}$ genoma humano contém entre 50.000 e 100.000 genes, ou seja, cerca de 3 bilhóes de nucleotídeos ou bases.

Trata-se de traçar, pela primeira vez, a cartografia do patrimônio hereditário da humanidade. Trata-se também de dissociar o normal do patológico, do ponto de vista da genética molecular, visando a descobrir e entender fisiopatologicamente as doenças genéticas (cerca de 3.000) que afetam o gênero humano. Não se trata de biotecnologia no sentido estrito, mas de genética e biologia moleculares; todavia, as aplicaçóes no âmbito médico e farmacêutico correspondem às biotecnologias. É provável que a localização do gene, cuja ausência ou disfunção é causa de doença hereditária, permita realizar sua substituição ou reparação abrindo caminho, desse modo, à terapia genética. Assim, as falhas inatas do metabolismo imputáveis à deficiência de uma enzima específica (enzimopatia) ou de uma proteína circulante no sangue (como o fator antihemofílico VIII) podem ser corrigidas pela inserção correta do gene normal. Por exemplo, a carência de adenosina desaminada (ADA), causa de grave imunodeficiência (que obriga a isolar os recém-nascidos afetados em uma bolha), poderia ser reparada com a introdução do gene 
controlador da síntese dessa enzima nas células da medula óssea ou transplantando uma medula óssea compatível que contenha esse gene. Posteriormente poder-se-ia aplicar, ainda que com maior dificuldade, o tratamento de hemoglobinapáceas, como a talassemia ou a hemofilia, proteinopáceas que poderiam também ser tratadas pelo transplante de medula óssea, cujas células contenham os genes normais dessas proteínas.

Dos 250 laboratórios de todo o mundo, atualmente participando do Programa, muitos trabalham em genomas menores que o genoma humano. Além da planta Arabidopsis thaliana, da bactéria Bacillus subtilis, estuda-se desde 1987 no Medical Research Council de Cambridge, no Reino Unido, o genoma do verme Caenorbabditis elegans (de um milímetro de longitude), que contém 2.000 genes e 100 milhöes de nucleotídeos. O da levedura de cerveja (Saccharomyces cerevisie) é 20 vezes menor que o do homem, isto é, aproximadamente 7.000 genes distribuídos em 16 cromossomos, $13 \%$ dos quais reconhecidos em maio de 1992. Publicado com o aval de 147 pesquisadores pertencentes a 35 laboratórios europeus, em 7 de maio de 1992, a seqüência completa do cromossomo 3 (um dos mais curtos da levedura) resultou de trabalhos financiados pela CEE no âmbito do Biotechnology Action Programme (Programa de Ação Biotecnológica); o custo da operaçáo ascendeu a 2,6 milhões de escudos. Estima-se que a metade do genoma da levedura deverá estar decodificada em 1995, e a totalidade no ano 2000: a seqüência dos cromossomos 5, 9,6 e l está sendo analisada nos Estados Unidos, Reino Unido, Japão e Canadá, enquanto a Europa trabalha com os cromossomos 2 e 1. Segundo os especialistas, a análise desses genomas não humanos deverá levar a importantes descobertas sobre o funcionamento dos genes.

Em 1992 os Estados Unidos investiram 1.200 milhóes de francos anuais no programa; a França, mais de 200 milhốes de francos; e o Reino Unido, quase 50 milhóes; o Japão escalonou orçamento superior a 500 milhóes de francos ao longo de dez anos. A decodificaçáo completa do genoma humano está prevista para o fim do século. Na verdade, os laboratórios podem estabelecer a sequiência de aproximadamente 100.000 nucleotídeos por ano, ao preço médio de 3 dólares por nucleotídeo, o que é considerado demorado e dispendioso. O Centro Riken de Ciências da Vida de Tsukuba, no Japáo, abrigando gigantesca cadeia automática, única no mundo, deve ter capacidade de decifrar mais de 100.000 nucleotídeos em vinte e quatro horas. Por outro lado, um empresário norte-americano tinha a intenção de criar, juntando $\mathbf{5 0}$ milhóes de dólares, uma sociedade privada para pôr em andamento uma 
cadeia seqüencial capaz de decifrar entre 50 e 100 milhóes de nucleotídeos por ano, durante cinco anos. Na França, o programa Genexpress, financiado pelo Centro Nacional de Pesquisas Científicas, pelo Ministério de Pesquisa (30 milhóes de francos em 1991) e pela Associação Francesa de Luta contra as Miopatias (90 milhóes de francos), integrado em estrutura sem fins lucrativos, o Généthon, conta com meios semiindustriais para estabelecer a sequiência do $\mathrm{ADN}$; os resultados obtidos sáo colocados à disposiçáo do conjunto da comunidade científica, enquanto as tendências que se observam nos Estados Unidos levam os pesquisadores a temer a poderosa influência do setor industrial.

Após a publicaçáo, em setembro de 1992, dos resultados obtidos por pesquisadores franceses do Centro de Estudos do Polimorfismo Humano em Paris, que trabalham no Programa Genexpress, existe a possibilidade de se ganhar de 4 a 5 anos reduzindo ao mesmo tempo em uma proporçáo de 5 a 10 o custo previsto inicialmente do programa Genoma bumano. Segundo essa mesma equipe, também será possível descobrir antes do previsto, entre l e 3 anos, em vez de 5 a 10 , os genes relacionados com algumas doenças de origem genética.

\section{Estratégias bioindustriais}

No setor de cultivos, ocorreu reorganização do mercado de sementes, propiciando maior integraçáo com o setor agroquímico (inclusive com os setores farmacêutico e petroquímico). Durante os anos setenta e começo dos oitenta, mais de $\mathbf{8 0 0}$ empresas que se ocupam da reprodução de cultivos, quase a metade do total mundial, foram adquiridas por outras empresas ou se fundiram com elas. Dez empresas intervieram em quase metade de todas as fusóes ou aquisiçóes. As estratégias inovadoras bioindustriais centraram-se nos cultivos híbridos e nas biotecnologias protetoras de cultivos como, por exemplo, em herbicidas, resistência aos vírus, bioinseticidas e fungicidas. A nova estratégia aponta para o controle do mercado de sementes ou, o que é mais importante, para chegar até os mercados com o objetivo de apropriar-se do valor industrial sinérgico.

As biotecnologias vão sendo incorporadas em todos os níveis da cadeia agroalimentar, convertendo os diagnósticos e as vacinas no principal centro de interesse das pequenas e médias empresas. Além disso, a aceitaçáo ou recusa pelo consumidor dos novos produtos influi na dedicaçáo das empresas às biotecnologias como, por exemplo, no emprego dos hormônios recombinados do crescimento ou as modificaçóes genéticas do gado. 
Leveduras, cepas para o tratamento dos produtos lácteos, enzimas e toda uma série de ingredientes alimentícios (sabores, aromas, agentes saponificantes, pigmentos) também fazem parte das estratégias bioindustriais. As enzimas são consideradas como substitutos dos processos convencionais de extraçáo química ou catalisadores para a bioconversão das matérias-primas básicas em sucedâneos dos produtos agrícolas.

No que se refere aos alimentos finais, a bioindústria deve decidir o tipo e o grau de sua integraçáo na cadeia agroalimentar, isto é, suas alianças com o abastecimento de matérias-primas, assim como seu compromisso interno e cooperativo com a pesquisa e o desenvolvimento biotecnológico. A resposta do consumidor cumpriria a funçáo determinante de orientar a inovação industrial, sobretudo no âmbito dos produtos geneticamente modificados.

O setor agroalimentar do Japão, que conta com atitude mais aberta por parte do consumidor e com exploraçáo geral do potencial da tecnologia da fermentação, tem traços próprios e apresenta sinergias reais entre as empresas produtoras de alimentos $e$ as de produtos farmacêuticos.

\section{Interesse dos consumidores e bio-segurança}

Os governos e a indústria compreenderam a necessidade de melhor informar o público sobre as novas biotecnologias, como também a participação de especialistas e de não-especialistas para avaliar a objetividade dessa informação; assim, a confiança do público na eficácia da regulamentaçáo deve aumentar consideravelmente. O público costuma associar as biotecnologias à engenharia genética ou às técnicas de reprodução humana, mais que à microbiologia industrial, à engenharia bioquímica ou às fermentaçôes, ou ainda associá-las a preocupaçōes com inocuidade dos alimentos ou ao serviço sanitário público que não têm absolutamente nada a ver com elas. Os grupos mais intelectualizados são os que aceitam melhor as biotecnologias. Seus adversários políticos mais ativos pertencem também a esses grupos, grande parte da oposição surgindo em virtude da preocupaçáo mais geral com o meio ambiente no setor mais instruído da populaçáo. No Japão, os resultados de diversas pesquisas demonstraram que a resistência às biotecnologias não procede de uma maioria não informada, mas de minoria bem informada, $90 \%$ da qual rejeitou as pretensóes dos pesquisadores de que a liberação de organismos geneticamente manipulados não acarreta riscos para o meio ambiente.

O Conselho Presidencial dos Estados Unidos sobre Competiti- 
vidade sustenta que é preciso eliminar cargas desnecessárias para que o país permaneça na vanguarda das biotecnologias, segundo seu Informe sobre a política nacional em matéria de biotecnologia. Diante do Fundo de Defesa do Meio Ambiente (EDF) e de vários outros grupos, pediu-se à administraçáo dos Estados Unidos que se oponha a todo esforço para criar, por meio de legislaçāo, novas estruturas regulamentadoras das biotecnologias, ou para modificar as já existentes. Não convém exagerar os riscos derivados dos organismos submetidos a técnicas biológicas, $\mathrm{e}$ - Informe sobre a politica nacional em matéria de biotecnologia afirma que "os produtos obtidos graças à biotecnologia, em si, não trazem riscos para a saúde humana nem para o meio ambiente". Defende o princípio da avaliação baseada no risco e náo no procedimento e um dos problemas importantes nesse sentido é saber por que se aceita determinado risco e o que aconteceria se esse risco nẩo fosse assumido.

\section{Problemas relacionados com a regulamentação da propriedade intelectual}

$\mathrm{Na}$ Europa, a proteção jurídica das culturas e dos animais geneticamente modificados não está tão clara como nos Estados Unidos ou no Japáo. Em abril de 1987, o Conselho de Apelaçōes e Interferências em matéria de Patentes da Agência Americana de Patentes e Marcas Registradas (UPSTO) havia julgado, no caso Allen, que as ostras poliplóides, para as quais se havia pedido patente, eram "produtos ou composiçóes de substâncias não existentes na natureza" e, por conseguinte, patenteáveis segundo as leis de patentes norte-americanas. Essa decisão levou a UPSTO a anunciar, três meses depois, que a Agência de Patentes e Marcas Registradas deveria considerar todos os "organismos vivos multicelulares artificiais e não humanos, compreendidos aí os animais, como patenteáveis". A esse anúncio seguiu-se a primeira patente de um mamífero, o onco-rato, em 1988.

A legislaçáo européia, com base na Convençăo Européia de Patentes proíbe, em princípio, patentear variedades de vegetais e animais, contrariamente à legislaçáo americana. Os reprodutores europeus de cultivos aceitaram a necessidade de reforçar a proteçáo jurídica por diversos meios e, após alguma oposiçáo inicial, deram-se conta das vantagens da proteção das patentes concedidas aos cultivos geneticamente modificados. A oposição às patentes para animais na Europa já não procede fundamentalmente dos meios jurídicos, mas dos movimentos de proteçáo aos animais e ao meio ambiente. 
No que se refere ao genoma humano, em junho de 1991, os Institutos Nacionais da Saúde (NIH) dos Estados Unidos apresentaram à Agência Norte-americana de Patentes uma primeira solicitação de patentes para 347 seqüências parciais de ADN humano, isto é, fragmentos de genes dos quais não se conhece a natureza nem a eventual função biológica. Em 12 de fevereiro de 1992, o Diretor dos NIH declarou que "era seu dever obter benefícios das pesquisas financiadas com os impostos" e fez nova solicitação relativa a 2.375 seqüências suplementares, equivalentes no total a quase $3 \%$ do genoma humano; em 14 de junho de 1992, os NIH apresentaram nova solicitação nesse sentido à Agência Européia de Patentes. $O$ objetivo dessas solicitaçóes era duplo: por um lado, provocar o debate sobre a propriedade intelectual da genética humana e, por outro, obter prioridade sobre os direitos quanto às informaçóes conseguidas graças ao programa Genoma bumano, do qual se esperam importantes repercussóes econômicas.

Em 1991, o Comitê Nacional de Ética da França pronunciou-se pela não-comercialização do genoma bumano, posiçăo sustentada pelo ministro francês da pesquisa e do espaço, declarando, em dezembro de 1991, que "o intento de comercializaçáo de dados brutos procedentes do estudo do genoma humano suporia o final do que ainda hoje é um dos mais prodigiosos programas cooperativos do mundo". Em 15 de maio de 1992 o Comitê CAN-HUG, encarregado de assessorar a Comissão das Comunidades Européias sobre o Programa Genoma Humano, denunciou por unanimidade a concessão de patentes a fragmentos de ADN humano com funçáo desconhecida e pediu acordo internacional a esse respeito. Participou também nesse consenso o Japão, cujos responsáveis científicos se haviam pronunciado pela livre circulaçáo dos dados procedentes do estudo do patrimônio hereditário humano.

Entretanto, no Reino Unido, o Conselho de Pesquisa Médica, organismo que coordena as pesquisas sobre o genoma, anunciou em abril de 1992 um projeto de solicitação de patentes para mais de $\mathbf{2 . 0 0 0}$ seqüências parciais de $A D N$. Em julho de 1991 esse organismo já havia proclamado sua intenção de obrigar os industriais a pagarem pelo acesso a sua base de dados genéticos.

Nos Estados Unidos, a posição dos NIH é objeto de polêmicas: além dos protestos de numerosas personalidades científicas e da demissão de James Watson, pai do projeto Genoma bumano, a Fundaçáo Nacional da Ciência e o Departamento de Energia opuseram-se ao princípio do direito de patente das seqüências genéticas parciais. A poderosa Associação de Biotecnologia Industrial, que agrupa $80 \%$ das sociedades 
norte-americanas de biotecnologia, manifestou também sua oposição a esse tipo de patentes.

Dirigiu-se um apelo à UNESCO objetivando a realização de uma convenção internacional que permita proteger o genoma humano de toda patenteabilidade, pois, além de ser patrimônio comum a toda a humanidade, trata-se de seu patrimônio genético. Uma convençáo desse tipo, considerada complexa, teria inicialmente a vantagem de pôr um pouco de ordem na atual confusão científica, econômica e ética. A esse respeito, merece destaque a iniciativa do professor François Gros, da Academia de Ciências e do Instituto Pasteur de Paris, de facilitar à UNESCO os dados obtidos por equipes francesas no estudo do genoma humano.

\section{Conseqüências econômicas}

Até o início da década de $\mathbf{9 0}$, as avaliaçóes realizadas sobre as repercussões econômicas das biotecnologias alimentares eram raras $\mathbf{e}$ fragmentárias. Vale a pena assinalar que em alguns países fizeram-se previsóes econômicas quantitativas com relação ao hormônio bovino do crescimento e a outros medicamentos e produtos farmacêuticos.

As estimativas conjuntas das repercussóes na produçáo agrícola e os balanços comerciais publicados para Estados Unidos e Europa evidenciam que as biotecnologias podem aumentar a produtividade reduzindo os custos por unidade de produção (por exemplo, menos insumos químicos) ou aumentando o rendimento por unidade de produçáo. As previsōes no início desta década indicavam possíveis aumentos da produçáo leiteira de 10 a $16 \%$, em um período de 5 a 10 anos, caso se aplicasse o hormônio bovino do crescimento. Essa aplicação, por tempo mais prolongado, teria grande influência na produçáo leiteira e na estrutura agrícola se o novo produto se mostrasse rentável.

As biotecnologias acelerariam as mudanças estruturais em andamento do setor agroalimentar, orientando-o para melhor integração vertical da agricultura com os demais segmentos anteriores e posteriores. Espera-se que o ritmo de adoção das biotecnologias aumente paralelamente às dimensốes das explorações agrícolas, medidas mais por seu potencial de rendimento do que por sua superfície.

Espera-se que as biotecnologias reforcem as tendências a longo 
prazo para reduzir a mão-de-obra total na agricultura. Os responsáveis internacionais no campo das biotecnologias poderiam aumentar suas quotas de mercado internacionais, economizando assim mão-de-obra na agricultura, se as políticas comerciais o permitissem. As reduçóes de emprego poderiam ser compensadas, em parte, pela criaçáo de empregos em outros setores, sobretudo no de serviços relacionados ao setor alimentício. A difusão de tecnologias agrárias e alimentares nos países da OCDE será um processo gradual ao longo da década de 1995-2005, sem efeitos desestabilizadores importantes na estrutura social do emprego. Segundo um estudo publicado em 1985, a repercussão das biotecnologias na agricultura far-se-á sentir até o ano 2008 nos países em desenvolvimento; em 1996, nos Estados Unidos e na CEE; e em 1998 no Japão. Ainda de acordo com esse estudo, as datas previstas sáo: 2020, 2008, 2009 e 2011 para a silvicultura; 2010, 1997, 1997 e 1998 para os ingredientes alimentícios; 2016, 1999, 2000 e 1997 para os produtos químicos industriais; 2005, 1990, 1990 e 1990 para a medicina; 2021, 2009,2012 e 2015 para a mineração; 2023, 2002, 2002 e 2002 para o controle da contaminação, e 2020, 2019, 2010 e 2008 para a energia.

\section{As biotecnologias e os países em desenvolvimento}

Os anos $\mathbf{8 0}$ foram caracterizados pela introdução das biotecnologias nos países em desenvolvimento, com diferentes graus de prioridade e complexidade, o que ilustra não só as diferentes condiçóes econômicas e de desenvolvimento científico desses países, como também as diversas possibilidades de aplicação das biotecnologias em níveis de investimento e complexidade adequados a cada situação concreta (Sasson \& Costarini, 1990; Sasson \& Costarini, 1991).

Não se discute se os países em desenvolvimento devem elevar o gradiente das biotecnologias (ver Figura 1): os sistemas nacionais melhor preparados já estão em pleno andamento. Até os menores e mais pobres vêem-se obrigados a pensar em desenvolver e utilizar as biotecnologias modernas. Por exemplo, num país onde a maior parte dos cultivos fosse representado por um alimento básico, poder-se-ia investir proficuamente em um laboratório de cultivos de tecidos que, com investimento de capital de cerca de $\mathbf{2 0 . 0 0 0}$ dólares, permitiria importar cultivo de tecidos, clones sem vírus nem enfermidades, desenvolvidos em centros de pesquisa do exterior, e multiplicá-los rapidamente caso fossem adaptáveis às condiçôes locais e aceitáveis pelos produtores e consumidores. 


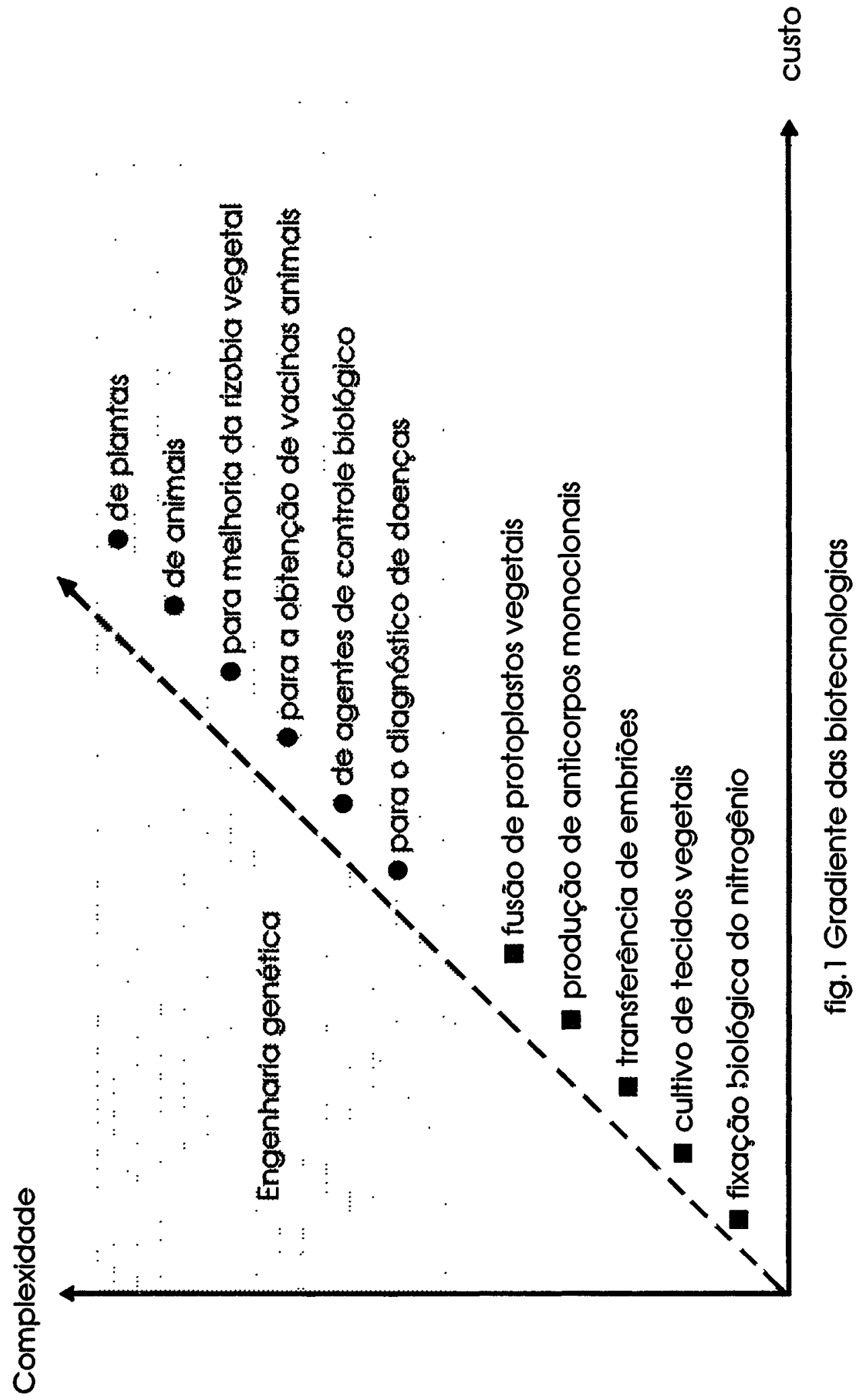


A ascensão pelo gradiente dependeria dos avanços posteriores das ciências fundamentais, sobretudo em certas áreas como a cartografia dos genomas. Convém lembrar que há duas variáveis a serem consideradas: o ritmo do progresso das ciências fundamentais e o ritmo com que os descobrimentos poderiam transferir-se para tecnologias amplamente utilizáveis.

O exemplo da agricultura na Ásia pode ilustrar a importância das biotecnologias para o Terceiro Mundo. No princípio da década de $\mathbf{9 0}$, esse continente contava com mais de $\mathbf{5 0 \%}$ da população mundial, mais de $70 \%$ das famílias agricultoras do mundo e apenas $25 \%$ das terras aráveis do planeta. No início do século XXI, a disponibilidade de terra per capita será de 0,1 hectares na China e 0,14 hectares na Índia. $O$ índice de crescimento da população na Ásia é de $1,86 \%$. A solução que resta a países como China e India para alimentar sua população crescente é melhorar continuamente os rendimentos. Com essa finalidade, a China dedicou-se à exploração em grande escala dos híbridos do arroz. As biotecnologias poderiam contribuir para aumentar a produtividade dos principais cultivos.

Desde 1950, foi quase triplicada a superfície irrigada do mundo, e grande parte desse aumento ocorreu nos países em desenvolvimento. A possibilidade de nova expansão foi gradualmente reduzida. Assim, melhor ordenamento dos recursos hídricos e incorporação de genes com resistência à seca nos principais cultivos são necessidades urgentes.

Relativamente à criação de gado, as necessidades dos países em desenvolvimento poderiam ser parcialmente satisfeitas com a aplicação de biotecnologias para aprimoramento genético, medicina veterinária $\mathrm{e}$ nutrição.

Estima-se que, graças às biotecnologias, os seguintes objetivos podem ser alcançados:

- na agricultura: milho resistente ao gorgulho de renovo (tecnologia já existente), mandioca resistente aos vírus (existente), mandioca enriquecida em proteínas (a longo prazo), batata resistente à lagarta (em futuro próximo), batata resistente aos vírus (existente), algodão resistente aos vermes (existente) e ensaios de diagnóstico de doenças provocadas por fungos (em futuro próximo);

- na sauide humana: vacinas contra a hepatite B (existente), contra a esquistossomose (em futuro próximo) e contra a malária (a longo prazo). 
Afirmou-se ser necessária pesquisa mais que excelente em biotecnologias para se chegar ao êxito comercial. Isso depende de uma série de requisitos prévios que têm relação com a capacidade social, compreendendo serviços para a difusão dos conhecimentos e condiçóes facilitadoras da mudança estrutural. A entrada na fase de pesquisa admite o risco de que os resultados sejam comercializados em outro país se não houver capacidade para ir mais longe.

As principais preocupaçóes dos cientistas e dirigentes políticos do Terceiro Mundo com relação às atuais tendências mundiais quanto aos objetivos e à organização da pesquisa e do desenvolvimento biotecnológicos são:

- A revolufão biotecnológica pode contribuir para ajudar os camponeses com poucos recursos a aumentarem sua produtividade?

- A possível repercussão negativa das pesquisas em engenharia genética direcionadas a encontrar substitutos para os produtos nacionais prejudicam o setor agrícola em sua atividade exportadora; alguns exemplos são os xaropes de milho ricos em frutose e outros edulcorantes naturais ou sintéticos, como sucedâneos do açúcar de cana ou de beterraba, assim como possíveis sucedâneos do aroma de baunilha, da manteiga de cacau e da diosgenina extraída da dioscorea.

- Os aspectos de bio-segurança da engenharia genética e, em particular, a possível utilização dos países em desenvolvimento como campo de experimentaçăo dos organismos geneticamente modificados escapam às estritas regulamentaçóes vigentes nos países industrializados.

- A repercussão da extensão dos direitos de propriedade intelectual aos genes e genotipos individuais para a disponibilidade desse material melhorado nos países em desenvolvimento e para os agricultores com poucos recursos. Os direitos de propriedade intelectual ficariam exclusivamente reservados para premiar a inovação formal, embora o sistema de inovação informal tenha desempenhado e continue desempenhando um papel-chave na identificaçáo e conservação dos recursos genéticos animais e vegetais?

- A orientaçáo para o mercado da pesquisa biotecnológica deve equilibrar-se com o bem-estar da humanidade a longo prazo, independentemente de os seres humanos serem ricos ou pobres. A pesquisa sobre os cultivos que são alimentos básicos nos países em desenvolvimento deve contar com o apoio internacional e não ficar como trabalho exclusivo desses países, em prol de desenvolvimento global 
e humano sustentável, dentro de espírito de solidariedade. O mesmo cabe dizer das doenças que prevalecem no Terceiro Mundo e exigem esforço internacional.

No que se refere ao potencial das biotecnologias agroalimentares na substituição dos cultivos tropicais e o estímulo da concorrência entre diferentes fontes de matéria-prima, algumas avaliaçóes mais realistas são menos alarmistas. A crescente universalização da indústria reduziu as pressões locais ou nacionais orientadas para a substituição, pressóes essas mais influenciadas por argumentos de nutrição e saúde que pelo custo. Esses argumentos não trabalhavam contra os cultivos do Terceiro Mundo e, além disso, a maior demanda de aditivos naturais poderia compensar, em parte, as perdas que os países em desenvolvimento sentiram com a substituição.

\section{Conclusão}

Como conseqüência dos descobrimentos em biologia e genética molecular conclui-se que o desenvolvimento e o aperfeiçoamento presente e futuro - das biotecnologias estão provocando mudanças profundas nas esferas econômica e social, pois as atividades bioindustriais projetadas referem-se à produção agrícola e à nutriçâo, ao tratamento e prevenção das doenças, à satisfação das necessidades em matéria de energia e à proteção do meio ambiente. $\mathrm{O}$ apogeu das biotecnologias nos numerosos campos de sua utilização a serviço do homem mostra-se muito promissor, e a cooperação internacional deverá desempenhar importante função na sua concretização.

Nesse trabalho e para essas perspectivas, como escreveu Heisenberg, "o homem encontra-se apenas com sua obra; e como não se trata de ir para trás, o homem náo tem outro remédio senáo dominar sua própria obra e sua complexidade" . É precisamente o caso das biotecnologias, resultado de décadas de pesquisa biológica, caracterizadas por descobrimentos, inovaçóes e também complexidade.

Da mesma forma, é necessário levar em conta os desafios de caráter ético colocados pelo desenvolvimento das biotecnologias. Por exemplo, os espetaculares resultados obtidos pelos pesquisadores franceses na decodificação rápida do genoma e publicados pouco antes da reunião Human genome. 92 - prevista pela primeira vez fora dos Estados Unidos, em Nice, de 14 a 17 de outubro de 1992 - levantam a questáo das consequiências éticas de semelhante empreendimento. No que se refere às doenças hereditárias (causadoras de $30 \%$ da mortalidade infantil) e das doenças em que a herança tem importante papel, como diabetes, 
asma, alergias, reumatismo, mal de Alzheimer, obesidade e doenças cardiovasculares e cânceres, a elucidação das seqüências responsáveis de ADN permitirá compreendê-las melhor e preveni-las. Mas até onde se chegará nessa compreensão? A existência de um sistema de marcadores genéticos pode levar muito rapidamente a sua utilização no diagnóstico pré-natal ou a intervir no embriáo humano antes do seu implante no útero. Poder-se-ia também corrigir, na escala do gene, um defeito genético e preparar novos tratamentos. Esse procedimento poderá levar a se tratar melhor o indivíduo, mas também a melhorar geneticamente a espécie; daí o temor de um novo eugenismo.

$* * * * *$

Nessa grande transição histórica de fim de milênio, na qual deveremos revisar nossos hábitos, comportamentos e estratégias sociais e econômicas, mal adaptados ao ritmo do mundo contemporâneo e que precisam de inspiraçăo e força espiritual, é muito reconfortante que os ministros encarregados do conhecimento e de sua aplicaçáo se reúnam em Sevilha, tendo como objetivo o Quinto Centenário do Encontro de Dois Mundos. Sevilha é símbolo de partida, mas principalmente de retorno, um recíproco descobrimento de solidariedade, de dupla articulaçáo entre tempos e espaços.

Se os historiadores se propōem a meta de estudar o passado, a nós, cidadáos, cabe escrever o futuro, criá-lo, utilizando e aplicando os instrumentos essenciais da ciência para esboçar um futuro mais equiitativo e menos assimétrico. A grande lição do passado é que devemos percorrer juntos o futuro, atrever-nos a saber e saber atrever-nos. Atrever-nos a manifestar nossos pontos de vista, nossas discrepâncias, porque espetáculos patéticos como o da Somália nos indicam que a falta de ação já é cumplicidade na aldeia global.

A independência não é mais só política, nem tampouco a soberania é territorial; a independência se mede pela capacidade de interaçáo, e as culturas não se defendem pelo recolhimento, mas por sua capacidade de abertura. Existe a dependência dos conhecimentos, das tecnologias, dos bens culturais produzidos por alguns grandes países. Mas nenhum país pode ser apenas espectador do desenvolvimento científico, pois também deve ser ator. Cada povo que quiser traçar seus próprios horizontes futuros deverá contribuir, ainda que modestamente, para o acervo mundial do conhecimento e poder compartilhá-lo.

A América Latina não pode continuar com baixas taxas de pesqui- 
sa e desenvolvimento. Iniciativas como o Mercado Comum do Conhecimento (MECCO), o Programa Bolívar ou o Programa Ciência e Tecnologia para o Desenvolvimento (CYTED-D) são fundamentais para que o Estado e a sociedade civil invistam - como salientamos no documento da UNESCO apresentado na $2^{\text {a }}$ Cúpula Ibero-americana - no maior desafio do nosso tempo.

\section{Referências bibliográficas}

BULL, A.T.; LILLY, M.D. Biotechnology. international trends and perspectives. Paris, Organização de Cooperação e Desenvolvimento Econômico (OCDE), 1992.99 p.

MUNÓZ, E. Biotecnología: sueño, realidad, monstruo?Madrid, Consejo Superior de Investigaciones Científicas, Instituto de Estudios Sociales Avanzados, IESA, 1984. 32 p.

SASSON, A. Bioteclmologies and development. Paris, UNESCO/CTA, 1988. 361 p.

SASSON, A. Las biotecnologins: desafíos y promesas. Paris, UNESCO, Sextante 2, 1984. 338 p.

SASSON, A.; COSTARINI, V. (eds.) Biotechologics in perspective: socio-economic implications for developing countries. Paris, UNESCO, Estudos prospectivos, 1991. $166 \mathrm{p}$.

SASSON, A.; COSTARINI, V. (eds.). Plant biotechnologics for developing countries. FAO/CTA. 368 p.

VASIL, I.K. (ed.). Bioteclmology: perspectives, policies and issues. Gainesville, Florida, USA, University of Florida Press. 247 p

VASIL, I.K. (ed.). Biotechnology: science, education and commercialization. New York, Elsevier Science Publishing Co. 309 p.

VASIL, V.; CASTILLO, A.M.; FROMM, M.E.; VASIL, I.K. Herbicide resistant fertile transgenic wheat plants obtained by microprojectile bombardment of regenerable embryogenic callus. Bio/Telbnology, v.10, jun. 1992, p.667-674.

\section{Resumo}

As biotecnologias geram bens e serviços utilizando seres vivos ou partes deles. Esses procedimentos têm largo emprego em importantes setores econômicos, tais como agricultura, indústria farmacêutica, indústria de alimentos e bebidas etc. Recentes avanços da biologia celular e molecular permitiram uma revolufáo biotecnológica, aqui exemplificada pela engenharia genética. Neste trabalho discute-se os impactos da moderna biotecnologia na atividade econômica, destacando as estratégias das bioindústrias, os problemas de biosegurança (principalmente a liberação de organismos geneticamente modificados no meio ambiente), e os problemas de propriedade intelectual originados pela engenharia genética. Considerase também o papel das biotecnologias nos países em desenvolvimento onde, ao lado de novas oportunidades para o desenvolvimento econômico e social, há o risco da perda de vantagens comparativas 


\begin{abstract}
Biotechnologies consist in the use of living organisms, or parts of organisms, to make or modify products. These techniques have broad application in agriculture, biomedicine and food industry. Recent progresses in cell and molecular biology originated a bioteclmological revolution, here exemplified by genetic engineering. This paper discusses the economic impact of modern biotechnologies, stressing the bioindustry strategies, the problems of biosafety (mainly the release of genetically modified organisms into the environment) and the problems of patents originated by generic engineering. The role of biotechnologies in developing countries is discussed. In these countries the biotechnologies represent new opportunities for economic and social development but, also, bring the risk of loosing comparative advantages.
\end{abstract}

Federico Mayor é diretor geral da Organização das Naçóes Unidas Para Educação, Ciência e Cultura (Ưnesco).

Discurso feito pelo autor na reuniāo de cúpula Ibero-americana de Ciência e Tecnologia, realizada no dia 6 de outubro de 1992, em Sevilha (Espanha).

Tradução de Helena B. C. Pereira e Renata Signer. O original em espanhol Las biotecnologlas a principios de los noventa: éxitos, perspectivas y retos - encontra-se à disposição do leitor no IEA para eventual consulta. 